\title{
Possessive pour in the French Lexicon of the Ivory Coast and Language Contact*
}

\author{
Béatrice Akissi Boutin (Toulouse le Mirail/Cocody-Abidjan)
}

\begin{abstract}
Any variationist study of Ivory Coast French needs to take into account sociolinguistic considerations and systemic features of other contact languages. For instance, there is a specific usage of pour against which the interference hypothesis can easily be tested:

IF: Le kaki que je porte présentement, c'est pour un bachelier qui me l'a laissé avant de partir en fac, cadeau. (Lafage 2003: 676).

Avant de te moquer du linge de ta voisine, regarde si pour toi est propre.

In Ivory Coast French, pour (N/Pro) can display a variety of functions: it can be part of associative predications, it can stand for genitive phrases in an anaphoric construction, make reference to an object in relation with another and participate in various idiomatic expressions.

This paper has a twofold objective. First, I argue that pour (N/Pro) constructions has to be analysed as an empty headed "associative" noun phrase. Second, I will show the relevance of extra- AND intersystemic factors in accounting for language variation. Incidentally, the use of pour (N/Pro) constructions seems to be conditioned by the availability of similar constructions in other Ivory Coast languages on the one hand, such as baoule (o lic) or dioula (à tá), and, cultural needs on the other.
\end{abstract}

\section{$1 \quad$ Introduction}

The study of variation requires not only the study of the language system itself but also that of the languages in contact and the sociolinguistic situation. Indeed, the three types of factors, intra-, inter- and extra-systemic, are often mixed in the development of variation.

Among the inter-systemic factors, interference involves, in the general sense of Weinreich (1953: 1), reorganisation in the most highly structured areas of the system, due to the conjunction of several types of language influences. These are normally observed in contexts of language contact, at the individual or social level, which is indeed the case with the Ivory Coast. Lafage (2003: XLIX) cites the study by Hattiger (1981) of the causes of language change in "colloquial Abidjan French": the facts of reorganization on the model of the targetlanguage, or independently of the source as well as target-language, are in the majority compared to reorganization on the model of the source languages. The influence of the source languages is undoubtedly reduced, but undeniable. There is for example, in Ivory Coast

\footnotetext{
* An earlier version of this article formed the basis of a paper presented during a one-day workshop in honour of Suzanne Lafage, the text of which was later published in the proceedings.

I would like to thank Jérémie Kouadio N'Guessan and Kalilou Téra who helped us to delve to the functioning of Bawle and Jula. I would like to thank Francis Cornish too for his help in drafting this article in English.
} 
French, a particular use of pour, for which the hypothesis of syntactic interference can easily be verified.

But if such varieties of French may be explained by inter-systemic factors, it's also as a result of other extra-systemic factors. Among these the most decisive in Ivory Coast French variation are: the socio-cultural representation of the French of France and the French of the Ivory Coast, the requirements of communication in the Ivory Coast community and pressure of the exogenous and endogenous norms. The representation of the French of France is generally that of an old rigid language, the vehicle of French culture, undoubtedly valored in terms of a literary language, but which must be modernized and adapted to the African realities in order to be used in the Ivory Coast. The acquisition of the academic variety, officially close to the standard French of France, is justified by the need, both professional and cultural, to communicate with other parts of the world effectively and confidently. However, outside the academic context and that of higher education in particular, the pressure of the endogenous standard is much stronger than that of the exogenous standard. Ivory Coast French means an identity representation.

These factors predispose the Ivory Coast community to create new rules for Ivory Coast French, without cutting the ties with international French. There we find, in ways that may be unexpected, one of the conditions of interference: the divergence between the two languages in contact must be tiny so that a model of the source language can be integrated within the system of the "recipient language" (Weinreich 1953: 31). Thus we agree with Jakobson (1938) and Weinreich (1953: 23) who quotes him, both of whom refer to phonology: A language "accepts foreign structural elements only when they correspond to its tendencies of development." We also agree with the concept that Chaudenson et al. name "convergence":

[...] the tendency to eliminate a native variant with no compensation in the dominant language, to the advantage of a variant which has an equivalent in the dominant language. (Chaudenson 1993: 16)

The study of the varieties of French in Africa requires a consideration of methodologies that is no doubt more extensive than that needed for the variation of French in the western zones (America and Europe). Whereas officially, there exists for all Francophone countries only one standard French, that of metropolitan France, certain elements of this standard do not really go beyond the borders of France or of these Francophone countries. In addition, independently of standard French, we can observe elements of French which are common to all Francophone areas as well as elements specific to each country or area. We can then consider that the French of each area (France, Ivory Coast, etc) is made up of a "common French" in addition to the characteristics of each area or nation. We prefer to keep here the term "common French" for the French which can be used everywhere, rather than using that of "international French", on which very little research has been done up until now.

\section{Presentation of the form pour (N/Pro)}

The basic construction of the form pour (N/Pro) is a predicative construction: être pour (N/Pro), listed under the fourth entry for être by Lafage (2003). It appears in contexts such as the following:

IF: (1) La Mercedes c'est pour lui, le taxi que je conduis c'est pour lui, il en a vingtcinq en tout.

(2) Le kaki que je porte présentement, c'est pour un bachelier qui me l'a laissé avant de partir en fac, cadeau. (Lafage 2003: 363, 676)

In these predications formed in terms of the identificational construction in $c^{\prime} e s t$, the use of the preposition pour with a genitive value, not dative as in common French, is highlighted. 


\subsection{Discussion of the concept of "possession"}

This has to do with "associative predications" in Creissels (1979) sense in the typological context of his Thèse d'Etat; in other words, the predication of a relation of some kind: participation in the personal sphere. The concept of "personal sphere" stems from the fact that man is aware of a system of relationships which surrounds him, in which he feels more or less involved. "Possession", in other words the fact of laying claim to certain objects, is only a particular case. The concept of "possession" can then be restrictive, just as the corresponding expression used can be unsuitable, whenever the structure does not refer to the social right thereby indicated. In most cases, the specification of a name by a "human" complement is only one logical association of one entity with another human one. Creissels (1979) proposes the general term "associative" value for the connection with the personal sphere. Later, he uses the term "genitive" in the same sense (Creissels 1991).

\subsection{Possible genesis of the form pour (N/Pro)}

The genitive use of pour is attested since the time of colonisation in genitival phrases (termed in Creissels (1979) "associative determination"). Delafosse (1904) describes it as one of the three possibilities of the pidgin french phrase to translate le fusil de mon camarade:

(3) Le fusil pour mon camarade/Le fusil mon camarade/Mon camarade son fusil. (Delafosse 1904: 265)

While the didactic military document Le francais tel que le parlent nos tirailleurs sénégalais recommends it, instead of the structure with a "possessive", African speakers don't have to make the distinction between "feminine" and "masculine". In this way, expressions such as:

(4) case pour lui/case pour nous/case pour vous/case pour eux.

translate: $\quad$ sa maison/nôtre (sic) maison/vôtre (sic) maison/leur maison. (Le francais 1916: 9)

We have to do here with a neologism in terms of sense for an already existing form, which is accompanied by the creation of structures not attested in common French. We are here dealing with the interface between the lexicon, semantics and syntax.

This structure, which is no longer in current use, may be the precursor of associative predications such as: c'est pour lui and the reduced form: pour (N/Pro) of present-day Ivory Coast French.

\subsection{Referential values and functions assumed by the form pour (N/Pro)}

The use of the reduced form pour (N/Pro) is very widespread; it appears under two types of referential values: anaphoric (whether the antecedent is present in the context or in the situation) and generic. The syntax of the sequence pour (N/Pro) is that of a noun phrase, which can assume the functions of subject and complement. We have, in subject position, with anaphoric reference: 
IF: (5) Avant de te moquer du linge de ta voisine, regarde si pour toi est propre.

(www.nouchi.com (13/02/2001))

(F: Avant de te moquer du linge de ta voisine, regarde si le tien est propre. $)^{1}$

(Before laughing at your neighbour's washing, see if yours is clean.)

(6) Ce qui a fait dire à beaucoup que "couvre feu de [X]-là, ce n'est pas comme pour [Y]-là!" "(Soir info (13/12/2000))

(F: Le couvre-feu de [X] n'est pas comme celui de [Y].)

([X]'s curfew is not like [Y]'s.)

(7a) C'est pas le journal d'aujourd'hui, c'est pour la semaine dernière.

(F: C'est pas le journal d'aujourd'hui, c'est celui de la semaine dernière.)

(It's not today's paper but last week's.)

In subject position, under the generic value:

IF: (8) Ce qui est sûr, pour toi va marcher. (oral 1998)

(F: Ce qui est sûr, ton affaire va marcher.)

(One thing is sure: your business will prosper.)

(9) [Si Ali est vendeur] Pour Ali est cher.

(F: Les choses d'Ali sont chères/Ce que vend Ali est cher.)

(The things that Ali sells are expensive.)

(10) [Si le locuteur attend son tour] Pour nous est arrivé.

(F: Notre tour est arrivélC'est notre tour.) (Kouadio N'Guessan 1977: 214)

([When the speaker is waiting for his turn] It's our turn.)

With anaphoric reference, we have in complement position:

IF: (11) A cause de la maladie, son pied, on dirait pour éléphant. (oral 1998)

(F: A cause de la maladie, son pied, on dirait celui d'un éléphant.)

(Because of illness, his foot looks like an elephant's.)

(12) Poisson là, il faut me donner pour aujourd'hui.

(F: Il faut me donner du poisson d'aujourd'hui.)

(You have to give me today's fish.)

With a generic value, in direct object position:

IF: (13a) Je n'achète pas pour lui.

(F: Je n'achète pas ce qu'il vend.)

(I don't buy what he sells.)

\footnotetext{
1 The suggested translation is each time a semantic equivalent which is not necessarily a syntactic equivalent.
} 
(14) Je n'achète pas pour (Cocody/ici), j'achète pour (Adjaméllà-bas).

(F: Je n'achète pas les choses (de Cocody/d'ici), j'achète les choses (d'Adjamél de là-bas).)

(I don't buy things from (Cocody/here), I buy things from (Adjamé/there).)

With a generic value, in prepositional object position:

IF: (15) Ils vont enlever dans pour toi maintenant. (Niamien 1997: 98)

(F: Ils vont voler dans ce qui est à toi maintenant/Ils vont te voler maintenant.)

(They will steal something from you now.)

In all these sentences, the sequence in pour can be clefted:

IF: (7b) (Le) Journal (là), c'est pour aujourd'hui (que) je veux.

(13b) C'est pour lui (que) j'achète.

We also have frozen sentences constructed with the verbs dire and faire and their variants. In these sentences, pour has a generic value:

IF: (16a) Il a dit pour lui, laisse-le!

(F: Il a donné son avis, laisse-le!)

(He has given his view, let him be!)

(17) L'enfant a fait pour lui, or il n'a jamais appris à peindre. (oral 1998)

(F: L'enfant a fait à sa façon, or il n'avait pas appris à peindre.)

(The child has done it his way, and yet he wasn't taught how to paint.)

(18) Moi j'ai parlé pour moi, ho!

(F: J'ai dit ce que j'avais à dire.) (Niamien 1997: 84)

(I have said what I have to say.)

The clefting can also be applied to sentences such as (16b):

IF: (16b) Laisse-le! C'est pour lui il a dit.

This use of pour raises the question of the origin of linguistic change (here lexical and syntactic) in a situation of language contact and the categorial status of pour in these structures.

\section{Reduction or substitution, the light shed by Jula}

Is pour always a preposition introducing a complement of an implicit head noun? In this case we have a self-generated local formation which should be associated with reductions of noun phrases by deletion of the head noun, as in: La voiture de Guy et celle d'Eve, in common French. 
This possibility of reduction has been particularly studied by Creissels (1991: 57-62) in French and in Bambara ${ }^{2}$ which function in a rather similar way on this point. In these two languages, the syntax allows the deletion of the anaphoric head noun; the latter remains implicit via the maintenance of those elements which are normally associated with it: in French, the determiner and the prepositional complement and in Jula the postpositional complement. The complement can then continue to be interpreted as applying to a term structurally present but not overt, whose context makes it possible to restore identity.

\subsection{The facts of common French}

In common French we have:

F: (19) Ce chien est méchant, pas celui-ci.

(That dog is dangerous but not this one.)

(20) Je n'ai pas pris le couteau de Guy, j'ai pris celui d'Eve.

(I have not taken Seku's knife, I have taken Adama's.)

(21) Il n'a pas pris sa voiture, il a pris la mienne (celle de moi.)

(He didn't take his car, he took mine.)

In the particular case of genitival phrases and expanded noun phrases, French resorts to celui and its paradigm. Creissels (1991), like Coene (2001) in a different perspective, shows that celui is not a pronoun, but the combinatory alternative of the determiner $c e$ in reduced phrases. Using essentially distributional arguments, Creissels (1991: 204) highlights the property of certain determiners "of occurring whithout the notion they determine being lexically present in the noun-phrase", as the case of celui in (19) and (20), and la in (21). True pronouns

are forms which occupy the syntactic positions of nominal constituents and which are distinguished from the other nominal constituents by the possibility they have of representing in a minimal way a referent present in the situation. (Creissels 1991: 204)

From a generativist point of view, Coene (2001) postulates the existence of a functional head $\mathrm{D}$ whose maximal projection is $\mathrm{N}^{\prime \prime}$ (as the maximal projection of the sentence is $\mathrm{C}^{\prime \prime}$ ). Just as between $\mathrm{C}$ and $\mathrm{V}$ there exist several functional categories (tense, negation, agreement), so between $\mathrm{D}$ and $\mathrm{N}$ there exist several intermediate projections, sites where the features of possession, number and gender are located.

So we have in (19) and (20) a noun phrase with an empty head, in which celui is a demonstrative determiner. The noun complement $d^{\prime} E v e$ is maintained and the preposition of the reduced genitival phrase $(d e)$ has not changed.

\subsection{The facts of Jula}

Noun phrases with an empty head also exist in Jula, for example in the case of a demonstrative determination, as in the French example (19) already seen:

\footnotetext{
${ }^{2}$ See also Sangaré 1984: 280-289 for Jula.
} 

and Language Contact

Jula: (22) Wùlú nìn ká júgú, nìn mán júgú.

Chien Dem être-Pos méchant, Dem être-Nég méchant

(F: Ce chien est méchant, pas celui-ci.)

(That dog is dangerous but not this one.)

In Jula, the genitival phrase includes, in its longest form, the complement noun followed by the postposition tá, the whole preposed together with the head noun. This long form is used for alienable head nouns, on the basis of semantic criteria (natural relations, acquisition, emanations, parental, hierarchical, reciprocal relations, etc.) as studied by Sangaré (1984). In an anaphoric context, the head noun can be implicit. We thus have:

(23) $N$ má Sékù tá mùrú tà, $n$ kà Adámátá tà.

Pers1 Perf-Nég Sékou Postp couteau prendre, Pers1 Perf-Pos Adama Postp prendre

(F: Je n'ai pas pris le couteau de Sékou, j'ai pris celui d'Adama.)

( I have not taken Seku's knife, I have taken Adama's.)

(24) $\grave{a}$ mà $\quad \grave{a}$ tá móbili tà, $\quad \grave{a} \quad k \grave{a} \quad n \quad$ tá tà.

Pers3 Perf-Nég Pers3 Postp voiture prendre, Pers3 Perf-Pos Pers1 Postp prendre

(F: Il n'a pas pris sa voiture, il a pris la mienne.)

(He didn't take his car, he took mine.)

In (23) and (24), tá is a postposition in the genitival phrase (not reduced). In the case of anaphora and of reduction of the genitival phrase by deletion of the head noun, tá continues to occupy this position and makes the interpretation of the phrase possible. ${ }^{3}$

In the genitival phrase with an alienable head noun, tá does not appear, except in the case of reduction:

$\begin{array}{lllll}\text { Jula: (25a) } & \grave{a} \quad \text { den lò } & / & \grave{a} \quad \text { tá lò. } \\ & \text { Pers3 enfant PRES } & / & \text { Pers3 Postp PRES } \\ & (\mathrm{F}: \text { C'est son enfant } & / & \text { C'est le sien. }) \\ & (\text { It's her/his child } & / & \text { It's hers/his. })\end{array}$

As far as the "definite", "indefinite", "plural" marking are concerned, they are impossible on the reduced phrase in vehicular Jula. ${ }^{4}$ For example we have:

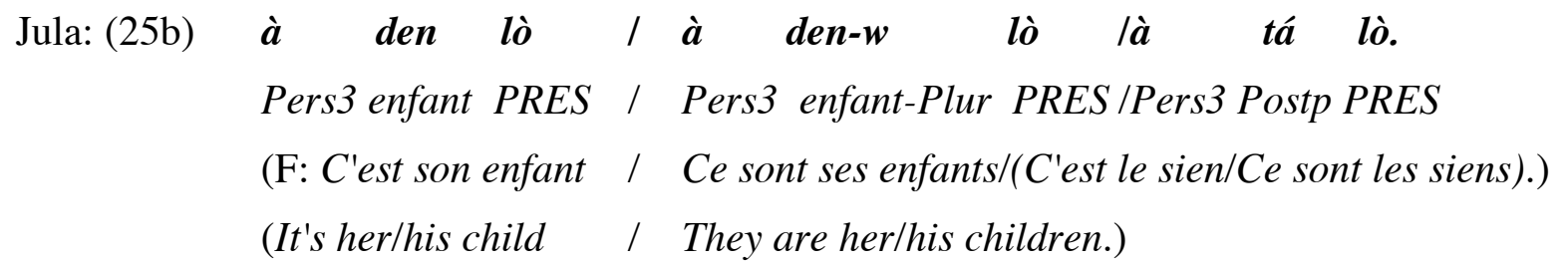

\footnotetext{
${ }^{3}$ Jula probably represents a state of language in which this postposition has lost its nominal value. In Bambara, there are two forms: $\boldsymbol{k} \boldsymbol{a}$ as a postposition for the genitival phrase complement which is not reduced, and $\boldsymbol{t} \boldsymbol{a}$ when it is reduced.

${ }^{4}$ In vernacular Jula, tá can receive the definite tonal morpheme which is usually placed at the end of the noun: à táà lò (C'est le sien) (It's his). (Sangaré 1984)
} 


\subsection{The interpretation of pour (N/Pro) in Ivory Coast French}

The case of pour (N/Pro) in Ivory Coast French must be compared with these facts. Capable of assuming all the functions of a noun phrase, pour (N/Pro) is indeed a pronoun, referring to a known entity, specified by another entity in relation to the first.

Pour can be interpreted as a preposition, in the same way as de in common French in (20), and the postposition tá in Jula. In Ivory Coast French, determiners are not obligatory so that the noun phrase has a grammatical function within a sentence and can refer to something. There still remains, in this variety, the noun complement, as in Jula, whereas in common French, where the determiner is obligatory, we have moreover a particular determiner: celui.

The implicit referent of the phrase with an implicit head pour (N/Pro) is identified via anaphora. We saw that pour (N/Pro) appears firstly in an anaphoric context, whether endophoric or exophoric. When it has a generic interpretation, the same procedure is involved: at the point of utterance of this anaphoric pronoun, the interlocutor will search for the referent in his memory, which can be replenished by the speech, the situation (short term memory) or other types of common extra-linguistic knowledge. The socio-cognitive context is then exploited to allow the interpretation of a reduction of the genitival phrase.

This type of structure in which the head noun is implicit is extended to other cases in Ivory Coast French, such as:

IF: (26) Ton grand père [Le père de ton papa] est toujours là? - Non, il est décédé, c'est chez ma maman qui est encore là. (oral 2004)

(Is your grandfather still here? - No, he is dead. It is my mother's father who is still alive.)

(27) [En essayant des chaussures] Si mon pied gauche rentre, à droite aussi peut rentrer. (oral 2005)

([The speaker is trying on some shoes] If my left foot fits, my right one does too.)

However, pour (N/Pro) is not strictly speaking a reduction but a substitution of a expanded noun phrase since, in addition to the absence of a head noun, we have a substitution of prepositions. We can thus put forward the hypothesis that the structure pour (N/Pro) is syntactically autonomous, even if it is used primarily in an anaphoric context, where the specific interpretation is facilitated. In the same way, in (26) and (27) chez ma maman and $a$ droite are constructed independently of a corresponding noun phrase. In support of this hypothesis, there is also the fact that prepositions have a semantic value which is much stronger in Ivory Coast French than in French of France, as in the case of the African languages of the Ivory Coast in which the nominal source of postpositions remains very close.

In this case, pour is to be considered itself as a substitute of the head noun of the genitival phrase, to which a complement noun or pronoun is juxtaposed: it is thus the real pronoun, itself referential. If this is the case, we have a juxtaposed structure, modeled on the Ivory Coast languages, since the French language does not have such structures. The contrastive connection of the structure pour (N/Pro) of Ivory Coast French with the equivalent structure (N/Pro) lic of Bawle is then illuminating. 


\section{Preposition or noun: the light shed by Bawle}

\subsection{The facts of Bawle}

In Bawle the reduction of the genitival phrase is performed by a particular morpheme lic, studied by Creissels/Kouadio (1977: 327-341). The genitive phrases have the following structure: the complement noun, followed optionally by the pronoun, is preposed to the head noun. Each of the two nouns can receive specification marking, as "definite", "indefinite", "plural", etc.:

\begin{tabular}{|c|c|c|c|c|c|c|}
\hline Bawle:(28) & táluà' $n$ & tánnín' & $n$ & / & jánvue & 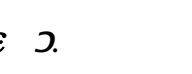 \\
\hline & fille Déf & Pers3 pagne & Déf PRES & / & Pers1 ami & PRES \\
\hline & (F: C'est le & gne de la fille.) & & / & (F: C'est un an & $m i(\grave{a} m o i))$. \\
\hline & (This is the & irl's loincloth.) & & / & (He is a friend & \\
\hline
\end{tabular}

LiE isn't obligatory and is used for emphasis:

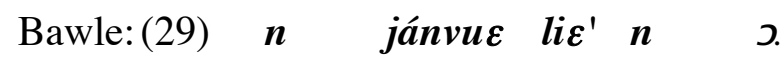
Persl ami part Déf PRES
(F: C'est mon ami (pas le tien).)
(He is my friend (not yours).)

In the case of reduction in an anaphoric context, lic exactly replaces the head noun base: it is a noun $^{6}$, in the sense part de, chose de, and syntactically it has the distribution of a relational noun (with an obligatory complement), as well as the properties of specification of the noun. For example we have:

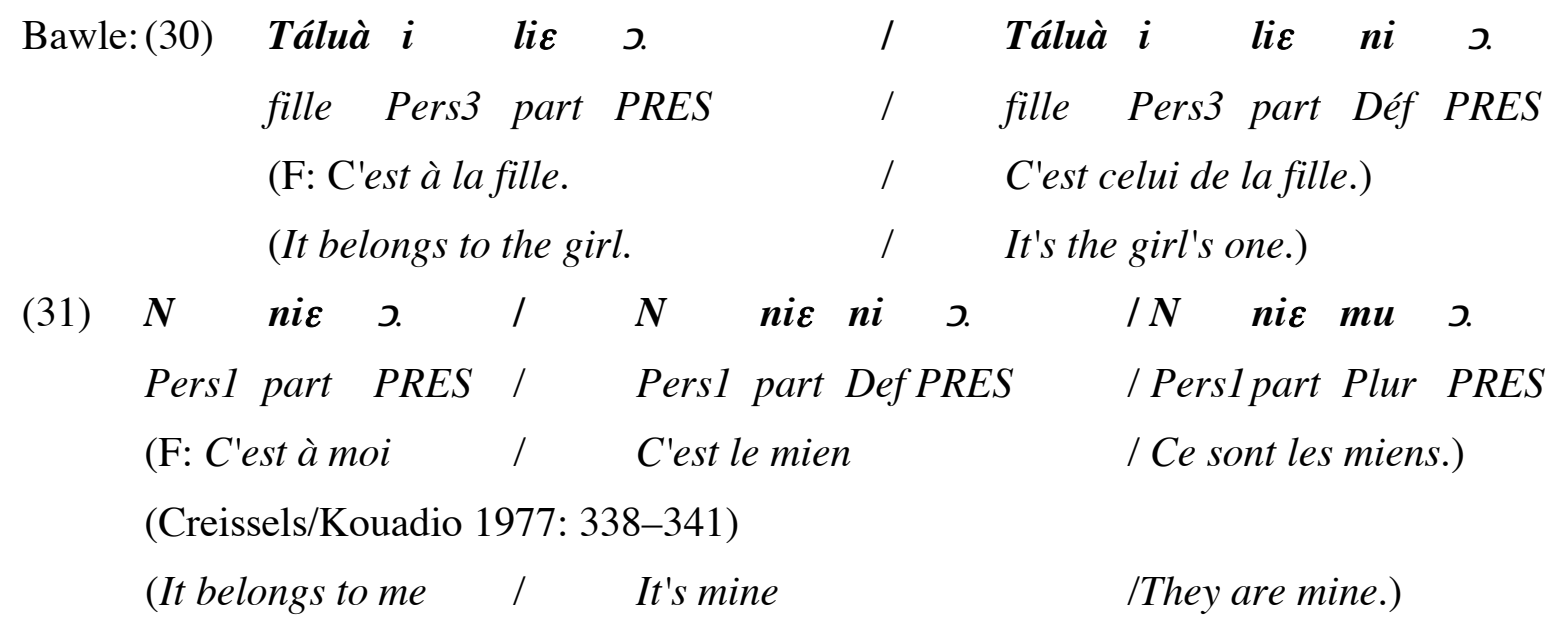

\footnotetext{
${ }^{5}$ We recall that we are dealing each time with a possible semantic equivalent.

${ }^{6}$ One potential etymology can come from li: this, that, this one.
} 


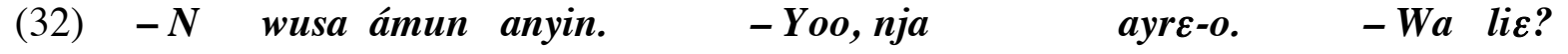

$$
\begin{aligned}
& \text { Pers1 dire Pers5 bonjour - oui Monsieur bonjour -Ici part? } \\
& \text { (F: - Je vous dis bonjour. } \quad \text {-Bonjour Monsieur. } \quad \text { - Et les nouvelles d'ici ?) } \\
& \text { (-Hello! - Hello sir. - What's the news from here?) }
\end{aligned}
$$

(N/Pro) lic can be used in all examples of Ivorian French from (5) to (10). Sentence (10), for example, is a translation from the following Bawle sentence:

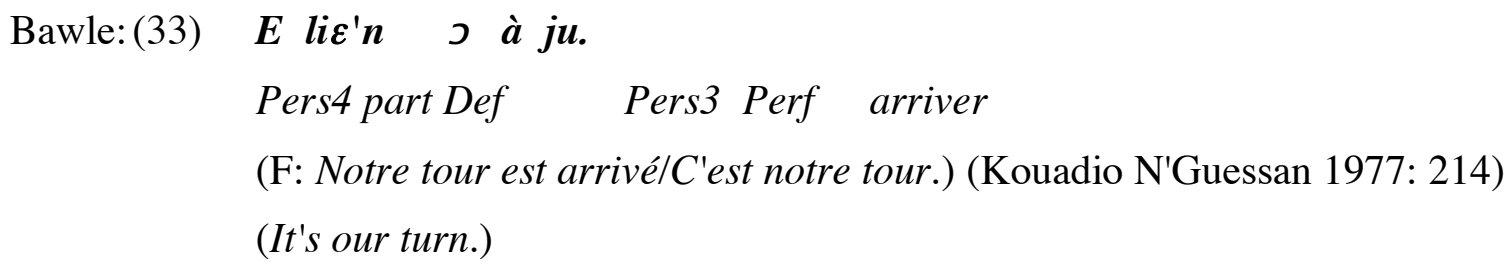

LiE has not lost its nominal nature and thus can carry all the specification marking of the noun. This is not the case with tá in Jula, nor of pour (N/Pro) in Ivory Coast French, for which no specification of a "definite" or "indefinite" value and of a number is possible. After pour (N/Pro), only là is possible as in (6) and in all the other examples. But là is not determining, in the usual sense of this term for the Romance languages. ${ }^{7}$

\subsection{The case of the frozen sentences}

Until now we have examined "associative" or "genitival" values of pour and their corresponding items in Jula and in Bawle. Looking at the fixed uses of (15) to (17), we firstly notice that the meaning of pour clearly moves away from that of "possession", and secondly they are not substitutions of an existing expanded noun phrase. But it is the same pour: these sentences retain the shared property of clefting; they also retain the concept of "relation to". These features are in fact modelled on African languages. We have for example:

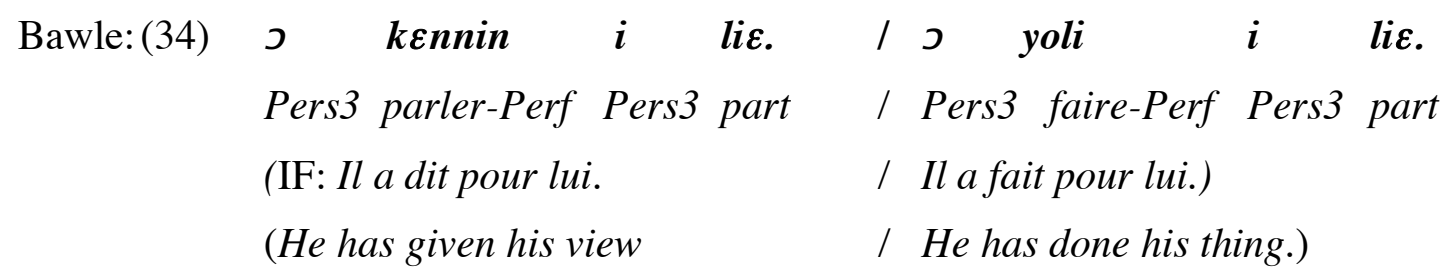

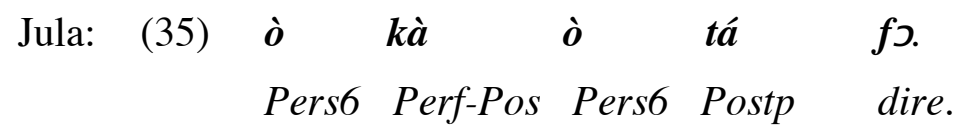

(IF: Ils ont dit pour eux./F: Ils ont dit leu avis.)

(They have given their view.)

We can also delve further into the semantic value of lie through its other uses. For example, Bawle uses the sequence (N/Pro) lic for the topicalisation of the subject:

\footnotetext{
${ }^{7}$ See for example Boutin (2002), Moseng (2002), Ploog (1999: 639-645).
} 

and Language Contact

$\begin{aligned} \text { Bawle:(36) } & \text { Yatyi, J lie, a kwlá wanndi tra min. } \\ & \text { Pardon Pers2 part Pers2 pouvoir courir dépasser Pers1 } \\ & \text { (F: S'il te plaît, toi, tu peux courir plus vite que moi.) (Tymian 1978) } \\ & \text { (Please, you can run faster than me.) }\end{aligned}$

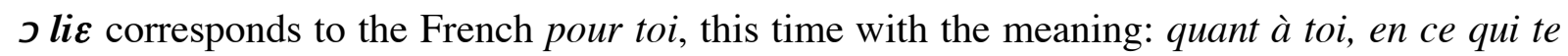
concerne.

Here again, Jula and Bawle differ: for topicalisation of the subject, Jula does not use the sequence (N/Pro) tá, but rather emphatic pronouns. This is with persons 1 to 6 : néle/íle/àle/ánwle/áwle/òle. For example we have:

$\begin{aligned} & \text { Jula: (37) àle bé móbili bòri. } \\ & \text { Pers3 Impf voiture conduire } \\ &\text { (F: Lui, il conduit. }) \\ &\text { (HE drives. })\end{aligned}$

On the other hand we have, for the Bawle example:

$\begin{aligned} \text { Jula: (38) } & \text { Sábari, ile bé sé bòrí-ì lá kàteme né kán. } \\ & \text { Pardon Pers2 Impf pouvoir course-Déf Postp dépasser Pers1 Postp } \\ & \text { (F: S'il te plaît, toi, tu peux courir plus vite que moi.) (Téra, personal } \\ & \text { communication) } \\ & \text { (Please, you can run faster than me.) }\end{aligned}$

In all these cases where the Ivory Coast French, Jula or Bawle have recourse to the morphemes pour, tá, lic, we are going beyond the "possessive" value to that of "concerning", so we again find the broader value of "relation to". We can postulate that interpretation is not achieved necessarily via an anaphoric process, but always via a metonymic one: a referent is indicated by a term which normally designates another entity which is related to it. This makes it possible to unify all the values observed in the examples.

\section{Conclusion}

In Ivory Coast French, the pronoun pour (N/Pro), a noun phrase with an implicit head, can enter into associative predications, substitute for a complete genitival phrase in the context of anaphora, refer to an entity by virtue of a relation with an another entity, and occur within frozen sentences. The use in Ivory Coast French of the structure pour (N/Pro) as an "associative" noun phrase with an empty head is supported by the existence of related structures in several Ivory Coast languages, including Bawle (N/Pro) lic and Jula (N/Pro) tá.

However, it seems that the internal structures of these three types of pronominal forms differ and may illustrate closely related states of the language, though which do not treat reduction of the genitival phrase in an exactly identical way. In fact, only lic has the referential function of a noun, the capacity to accept nominal specification morphemes, and to assume the syntactic function of head noun of a genitival phrase with an obligatory complement. The items pour and tá in the particular contexts that we described are preposition and postposition respectively, with semantic contents that are much more specific than the prepositions of common French. They don't have a referential function in themselves, since it's the unit 
(N/Pro) tá or pour (N/Pro) as a whole which has a referential function. The reference is normally actualized via the context, and if not, it remains generic.

This corresponds to the characteristics of Ivory Coast speech where a strong common presence of the interlocutors within the utterance situation is necessary for the construction of meaning in interaction. In Ivory Coast French, information which is given in common French via essential components of the sentence will be considered superfluous if it can be understood differently - that is, in terms of a common socio-cognitive context - and the items which express this information are not subject to the same constraints. They will be specified only in order to obtain an effect of redundancy. In other uses, they will be regarded as extra informative details, which it is not necessary to give where the utterance is initial.

Other functional aspects justify the use, in Ivory Coast French, of the pronominal form pour (N/Pro): the advantage of not having to be marked in gender and in number and that of using the paradigm of already existing complement pronouns: moi, toi, elle/lui, nous, vous, elles/eux. This aspect was already observed by Weinreich:

Significantly, in the interference of two grammatical patterns it is ordinarily the one which uses relatively free and invariant morphemes in its paradigm - one might say, the more explicit pattern - which serves as the model for imitation. This seems to be true not only in the creation of new categories [...], but also in those changes due to language contact where a new set of formants is developed to fulfill a preexisting grammatical function. (Weinreich 1953: 41)

In spite of this functional aspect, there is a significant difference between the functioning of Ivory Coast French and of "common" French. When it is a question of interference with African Languages, the issue will be: What could be the point of contact between "common" French and African Languages? It seems that there is no convergence between the syntax of these languages that are in contact: in "common" French, no prepositional phrase can be used as a noun phrase, which serves as subject or direct object. And yet this is one of the features of many African Languages, as in several instances: because of the fact that a noun phrase formed by a head noun and a postpositional complement phrase can occur where the head noun is implicit. Or even more because morphemes which serve as postpositions have not lost their nominal nature and, as a noun, can have a subject or direct object function. When they are used as postpositions, their status is close to that of a head noun of an expanded noun phrase. The only convergence between African systems and the French system is in the existence of adpositions (prepositions and postpositions) which allow the construction of adpositional phrases. Thanks to this single common feature, the interference enables one feature of the African languages to be integrated within the French system, and this has required a new analysis of the role of the French preposition.

The hypothesis of syntactic interference between the pronominal forms of Jula: à tá and Bawle: $\supset$ lic (and other equivalent forms in other Ivory Coast African languages) and the Ivory Coast French pour lui is here confirmed, as it is supported by cultural and functional needs.

\section{General notations:}

Perf, Impf: respectively "Perfective" and "Imperfective" values.

Pos, Nég: $\quad$ respectively "positive" and "negative" values.

PRES: $\quad$ presentative.

Postp: $\quad$ postposition associated with a noun.

Pro: $\quad$ pronoun. 
Pers1 to 6: $\quad$ grammatical persons, from values 1 to 6 .

Def, Dem: "definite" and "demonstrative" morpheme associated with a noun.

Plur: $\quad$ "plural" morpheme associated with a noun.

The orthography of Ivory Coast languages is the one used in Africa, notably in functional teaching of literacy or for those languages possessing an official spelling system; it does not correspond always to the IPA (International Phonetic Alphabet), even if it borrows two signs ( $\supset$ and $\varepsilon$ ) from it.

\section{References}

Chaudenson, Robert et al. (1993): Vers une approche panlectale de la variation du français. Paris (= Langues et développement).

Coene, Martine (2001): "La structure interne du SN à tête zéro". In: Kleiber, G. et al.: Typologie des groupes nominaux. Rennes: 235-250.

Creissels, Denis/Kouadio N'Guessan, Jérémie (1977) : Description phonologique et grammaticale d'un parler baoulé. Abidjan.

Creissels, Denis (1979): Les constructions dites "possessives", étude de linguistique générale et de typologie linguistique. Thèse de Doctorat d'État, Université Paris IV.

Creissels, Denis (1991): Description des langues négro-africaines et théorie syntaxique. Grenoble.

Delafosse, Maurice (1904): Vocabulaires comparatifs de plus de 60 langues ou dialectes parlés à la Côte d'Ivoire et dans les régions limitrophes avec des notes linguistiques et ethnologiques, une bibliographie et une carte. Paris.

Hattiger, Jean-Louis (1981): Morpho-syntaxe du groupe nominal dans un corpus de français populaire d'Abidjan. Thèse de 3e cycle, Université de Strasbourg.

Jakobson, Roman (1938): "Sur la théorie des affinités phonologiques des langues". In: Munksgaard, Ejnar: Actes du quatrième congrès international de linguistes. Tenu à Copenhague du 27 août au ler septembre 1936. Copenhagen: 48-59.

Le français tel que le parlent nos tirailleurs sénégalais. (1916), Paris.

Kouadio N'Guessan, Jérémie (1977): L'enseignement du français en milieu baoulé, problèmes des interférences linguistiques et socioculturelles. Thèse de $3 \mathrm{e}$ cycle, Université de Grenoble.

Lafage, Suzanne (2002, 2003): Le lexique français de Côte d'Ivoire, appropriation et créativité. Tomes 1 et 2. Le français en Afrique 16, 17.

Niamien, N'Gouan Ezéchiel (1997): Le français parlé dans les gares routières d'Abidjan. Mémoire de maîtrise, Université de Cocody. Abidjan.

Ploog, Katja (1999): Le premier actant en abidjanais. Contribution à la syntaxe du nonstandard. Thèse de 3e cycle, Université de Bordeaux 2.

Sangaré, Aby (1984): Dioula de Kong (Côte d'Ivoire). Phonologie, grammaire, lexique et textes. Thèse de 3 e cycle, Université Grenoble.

Tymian, Judith/Retord, Georges (1978): $N$ wan yo. Cours de baoulé. Abidjan.

Weinreich, Uriel (1953): Languages in contact. Findings and Problems. The Hague.

\section{Sources}

www.nouchi.com $(13 / 02 / 2001)$

Soir info $(13 / 12 / 2000)$ 